Int. J. Odontostomat.,

7(1):79-85, 2013.

\title{
Rapid Orthodontics with Flapless Piezoelectric Corticotomies: First Clinical Experiences
}

\author{
Ortodoncia Rápida con Corticotomías Piezoeléctricas sin Colgajo: \\ Primeras Experiencias Clínicas
}

Jorge Jofre*; Julio Montenegro* \& Roberto Arroyo ${ }^{* *}$

JOFRE, J.; MONTENEGRO, J. \& ARROYO, R. Rapid orthodontics with flapless piezoelectric corticotomies: First clinical experiences. Int. J. Odontostomat., 7(1):79-85, 2013.

ABSTRACT: One of the biggest challenges an orthodontic patient faces is the time spent wearing brackets. Over the years, several surgical techniques have been developed to address this issue and reduce the overall treatment time. These combine bone-healing mechanisms with orthodontic loads to accelerate tooth movement. Although effective, these techniques are also quite invasive in nature, requiring the elevation of buccal and lingual full-thickness flaps with extensive decortications of the buccal and lingual alveolar bone. Moreover, these techniques run the risk of teeth devitalization, avascular necrosis of the osseous block, alveolar resorption, and the risks of complications, with low acceptance by the patient. This manuscript reports three cases treated with a novel, flapless approach for minimally invasive rapid orthodontic (MIRO). This procedure includes radiographic-guided micro incisions and localized piezoelectric corticotomies. The clinical implications of this technique are discussed herein. MIRO reduces orthodontic treatment time, avoiding the reported adverse effects of accelerated orthodontics.

KEY WORDS: tooth movement, surgical procedures, minimally invasive, piezosurgery.

\section{INTRODUCTION}

Surgical procedures have been developed to reduce overall orthodontic treatment times, these techniques include 1) osteotomy (Koudstaal et al., 2005); 2) decortication (Sanjideh et al., 2010; Wilcko et al., 2009); 3) the Mono-cortical Tooth Dislocation and Ligament Distraction (MTDLD) technique (Liou \& Huang, 1998; Vercellotti \& Podesta, 2007). All these combine bone-healing mechanisms and orthodontic loads.

The biology associated with alveolar decortication, osteotomy and/or dental distraction techniques in relation to tooth movement have been clearly demonstrated (Lee et al., 2008). Authors claim that corticotomy accelerates treatments, when compared with conventional orthodontics (Vercellotti \& Podesta; Wilcko et al., 2009).
Wilcko et al. (2009) attributed the increased rate of tooth movement after corticotomy-facilitated orthodontics to a "regional acceleratory phenomenon" (RAP), which is characterized by greater bone turnover and a drop in mineral content (Bogoch et al., 1993; Frost, 1983).

The onset of RAP in alveolar bone is accompanied by a burst of osteoclastic activity resulting in lower bone density and augmented osteoblastic activity (Ferguson et al., 2001). Tooth movement is affected by alveolar mineralization, the greater the mineralization of the alveolar bone the more difficult teeth are to move (Kole, 1959). Moreover, osteoclastic activity is known to be integral to tooth movement. Thus, faster tooth movement is expected when stimuli lead to greater bone turnover and lower bone density.

\footnotetext{
Professor, Director, Center for Advanced Prosthodontics and Implantology, CRAI, University of Concepción, Chile.

" Center for Advanced Prosthodontics and Implantology, CRAI, University of Concepción, Chile.

${ }^{* * *}$ Private Practice,Center for Advanced Prosthodontics and Implantology, CRAI, University of Concepción, Chile.
} 
This technique has proven to be effective, but also invasive: a corticotomy surgery requires buccal and lingual full-thickness flaps with extensive decortications of the buccal and lingual alveolar bone, increasing postoperative discomfort and the risk of complications (Kim et al., 2009).

Surgical injury sets off a demineralization process and leads to high risk of alveolar resorption (Vercellotti \& Podesta; Wilcko et al., 2009; Wilcko et al., 2001). Noteworthy morbidity associated with osteotomy includes the risk of lost tooth vitality, avascular necrosis of the osseous block. Moreover, the procedure requires of a convalescence period, and the risks of general anesthesia. All this leads to low acceptance by patients (Chung et al., 2009; Kim et al.).

Aboul-Ela et al. (2011) using only buccal cortical perforations found that on the side where the corticotomy was performed individual tooth movement velocity was two to three times faster than on the control side. This result agrees with the findings of Wilcko et al. (2001, 2009), lino et al. (2007) Ren et al. (2007), Mostafa et al. (2009) and Cho et al. (2007) suggesting that the rapid rate of tooth movement seems to depend mostly on RAP rather than bony block movement.

Young-Guk et al. (2006) and Kim et al., introduce a flapless decortication in cats, by using a modified scalpel and mallet through the gingiva to inducing the RAP effect and moving the tooth faster during the orthodontic treatment comparing with the control group. This innovative technique was tested in this animal model. However, it has an important drawback, the repeated malleting could cause dizziness in real patients (Penarrocha-Diago et al., 2008).

Dibart et al. (2009) reported a tunneling procedure and localized piezoelectric corticotomies. However, the tunneling is an invasive and difficult procedure that does not allow corticotomies between each tooth, which is essential to create sufficient demineralization around the tooth for accelerated movements. The risk for root damage due to this blind technique is high.

The aim of this report is to present the clinical results of a minimally invasive rapid orthodontic procedure (MIRO), which maintains the advantages of speedy orthodontics described by Chung et al., but is a much less traumatic, as it is flapless, reducing both trauma and convalescence. MIRO also enhances accuracy by relying on radiographic surgical guides that help to make a precise corticotomy avoiding damage to vital structures and teeth.

Standardized Surgical Procedure. Patients who underwent the surgical procedure were periodontally healthy. Previous the intervention, each patient was informed about the benefits and possible risks of the procedure before signing the written informed consent. One day before surgery, patients rinsed with chlorhexidine $0.12 \%$ mouthwash twice (morning and evening).

Immediately before surgery, the patients rinsed with chlorhexidine $0.12 \%$ for 1 minute, and the peribuccal area was cleaned with gauze soaked in chlorhexidine.

All surgeries were carried out under local anesthesia (lidocaine hydrochloride 2\% with epinephrine 1:100,000). Radiographic metal guides were positioned between each tooth and digital radiographies were taken to assure that the metal pin did not project over the tooth roots. The metal pin was used as a strict guide to make mucoperiosteal incisions. The incisions began $2 \mathrm{~mm}$ below the papilla. An ultrasonic microsaw OT7 (Piezosurgery, Mectron Medical Technology) was placed over the incision. Using bone 1 cutting power and irrigation solution pump level 4 , vertical corticotomies were performed following the gingival incision trace.

After corticotomies, the patients were prescribed a soft diet and prohibited from using mouth rinse for $24 \mathrm{~h}$. No anti-inflammatory was indicated.

Patient check-ups were scheduled for $24 \mathrm{~h}$, day 7 , and then every two weeks for a month, performing adjustments if needed.

Case 1. A 22-year-old man with skeletal Class II and dental Class I was referred to the Center for Advanced Prosthodontics and Implant Dentistry, University of Concepcion in Chile. After 1.5 years of orthodontic treatment because the inferior teeth were difficult to move using conventional orthodontic forces (0.022-inch Roth brackets, in upper and lower arch, 0.016x 0.022 Nitinol). A radiographic examination did not show any abnormality. After talking with the patient, the proposed treatment plan was to carry out a flapless piezoelectric corticotomy. The patient accepted the treatment and signed an informed consent. During follow-up period, healing was uneventful (Figs. 1 and 2). At 1.5 months, the teeth had moved to the desired final position (Fig. 3). 


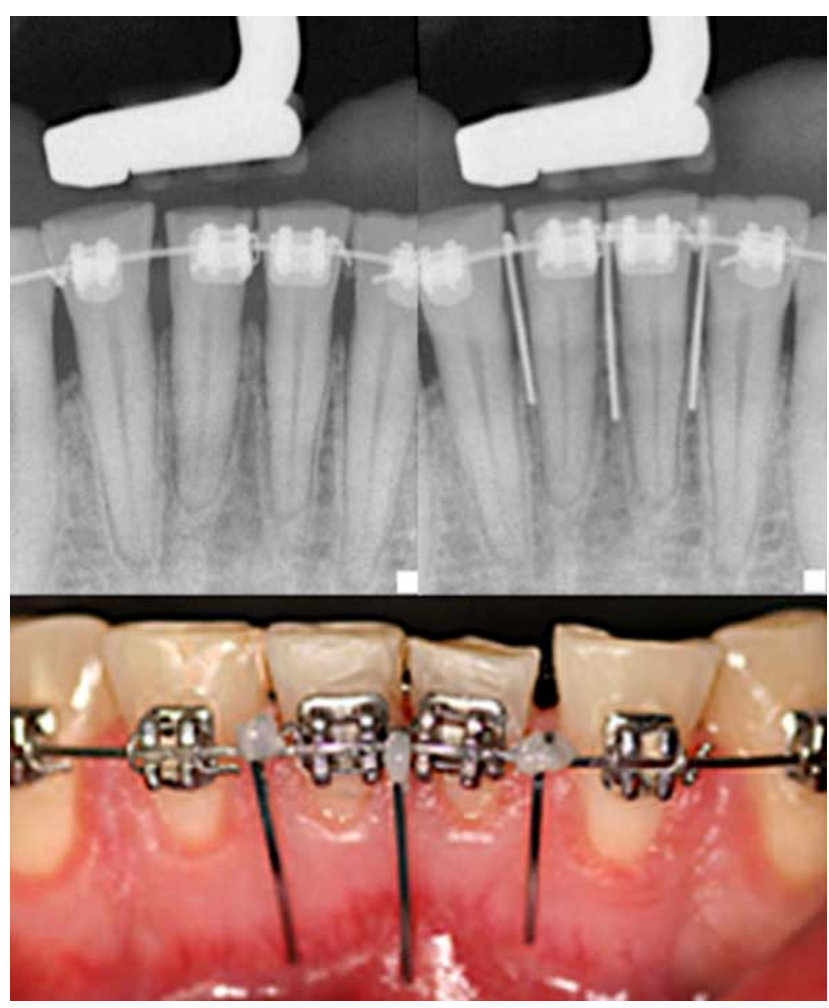

Fig. 1. The radiographic metal guides between each tooth were positioned and digital radiographies were taken to assure that the metal pin did not project over the tooth roots.
Case 2. A 37-year-old woman came to the clinic asking for a fast orthodontic treatment. She presented a skeletal Class I and dental Class II. Radiographic examination did not show any abnormality. The patient asked for a minimally invasive rapid orthodontic movement. One day after bracket placement $(0.022-$ inch Roth brackets, in upper and lower arch, 0.016x 0.022 Nitinol) a piezoelectric corticotomy was performed (Figs. 4 and 5). No major discomfort was reported by the patient at the post-operative period. At four months, she showed significant advances and the crowding was resolved at eight months, improving function and aesthetics.

Case 3. A 16-year-old girl came to the clinic asking for orthodontic assessment and rapid treatment. She presented a Class I, open bite malocclusion, high palate, and maxillary arch compression (Fig. 6). Radiographic examination did not show any abnormality. The proposed treatment plan was orthodontic treatment and maxillary corticotomy. One day after bracket placement $(0.022$-inch Roth brackets, in upper and lower arch, $0.016 \times 0.022$ Nitinol), a piezoelectric corticotomy between teeth was performed. Slight swelling of the soft tissue was observed during the first days post-operative. At two

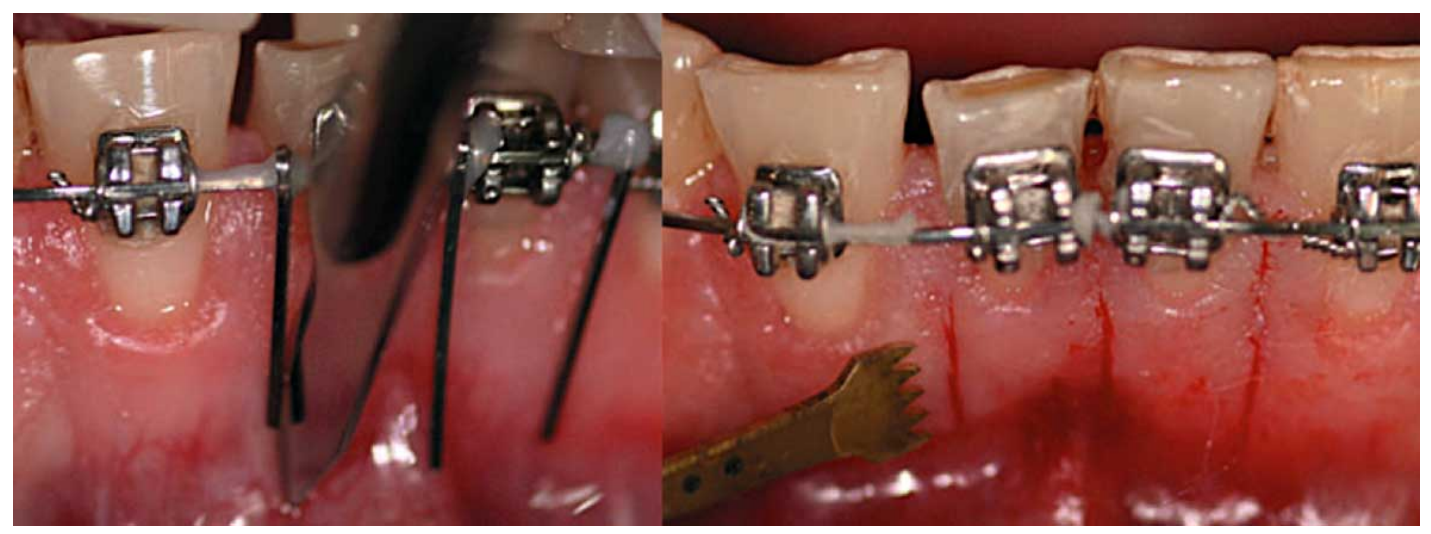

Fig. 2. The metal pin allows an accurate mucoperiosteal incision $2 \mathrm{~mm}$ below the papilla. Vertical corticotomies were performed using an ultrasonic microsaw OT7.

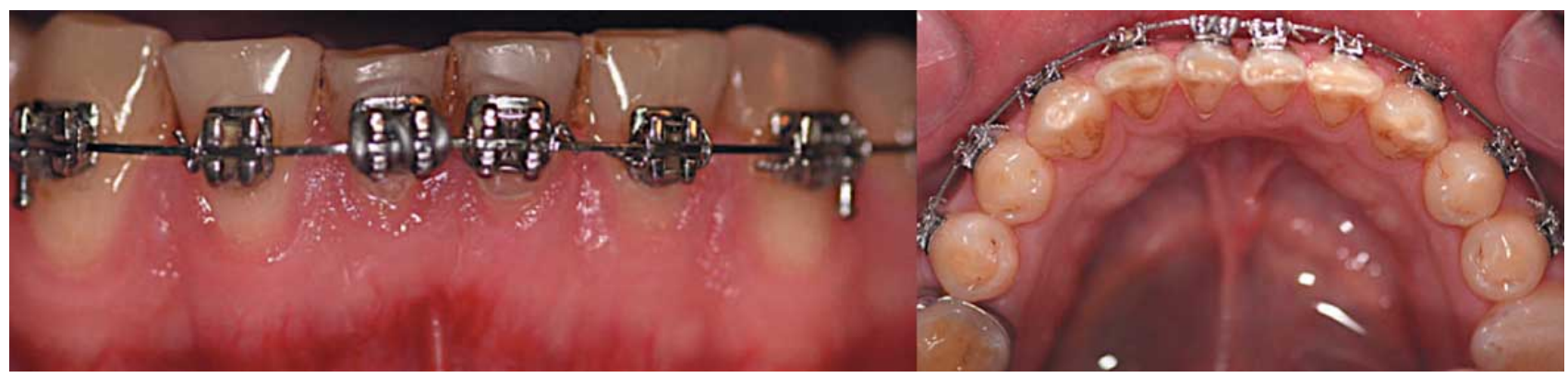

Fig. 3. Post-treatment frontal and mandibular occlusal view after 1.5 months. 
months, the appearance of the arch had changed considerably in the maxilla and mandible, and the crowding was corrected almost completely, such that the patient was ready for orthognathic surgery (Fig. 6).

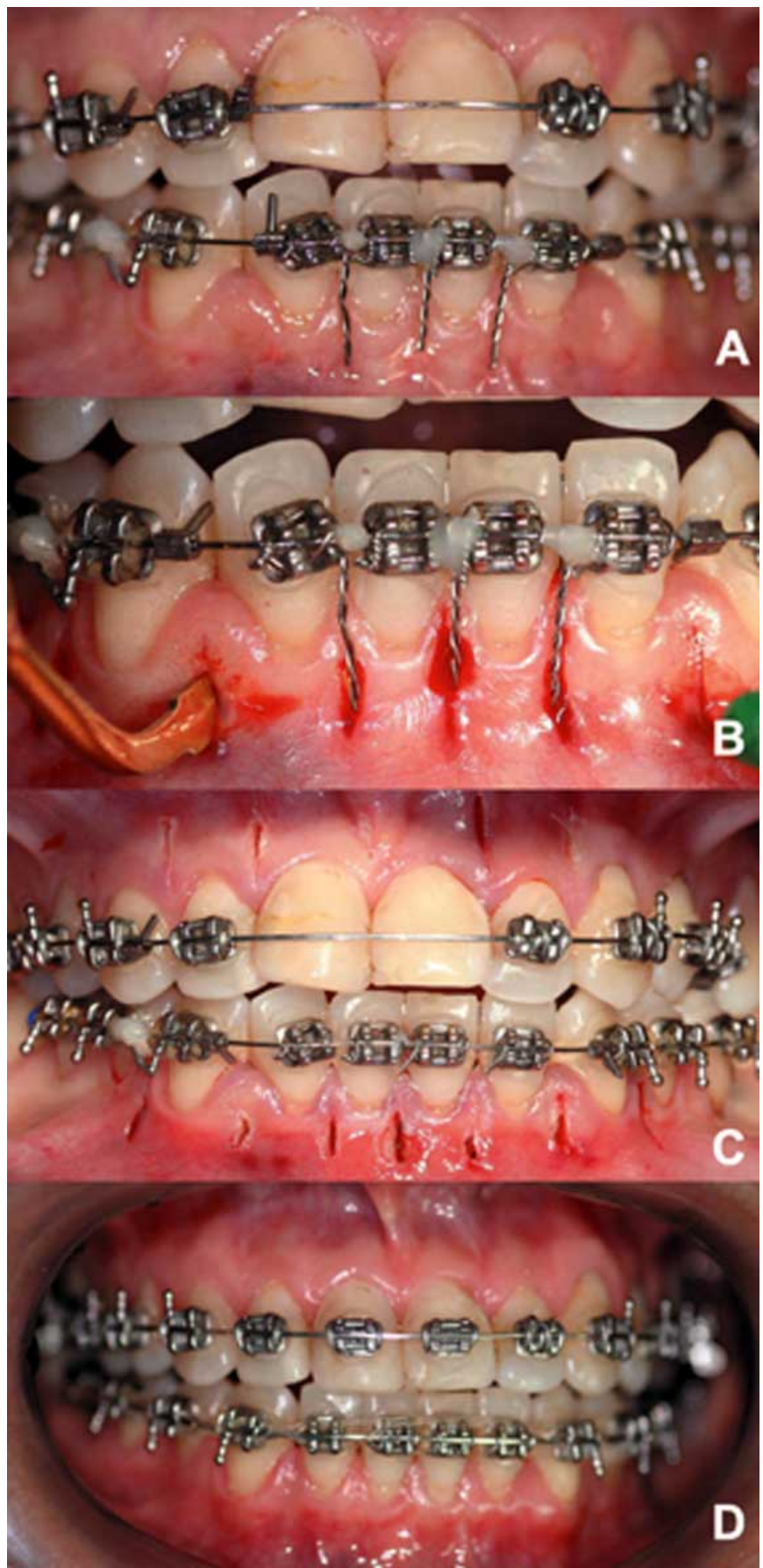

Fig. 4. A) Pretreatment frontal view showing the surgical guides placed where the incisions will be performed. B) Vertical corticotomies were performed following the gingival incision trace. C) Frontal view immediately after minimally invasive corticotomies. D) Frontal view four months after the surgical procedure.

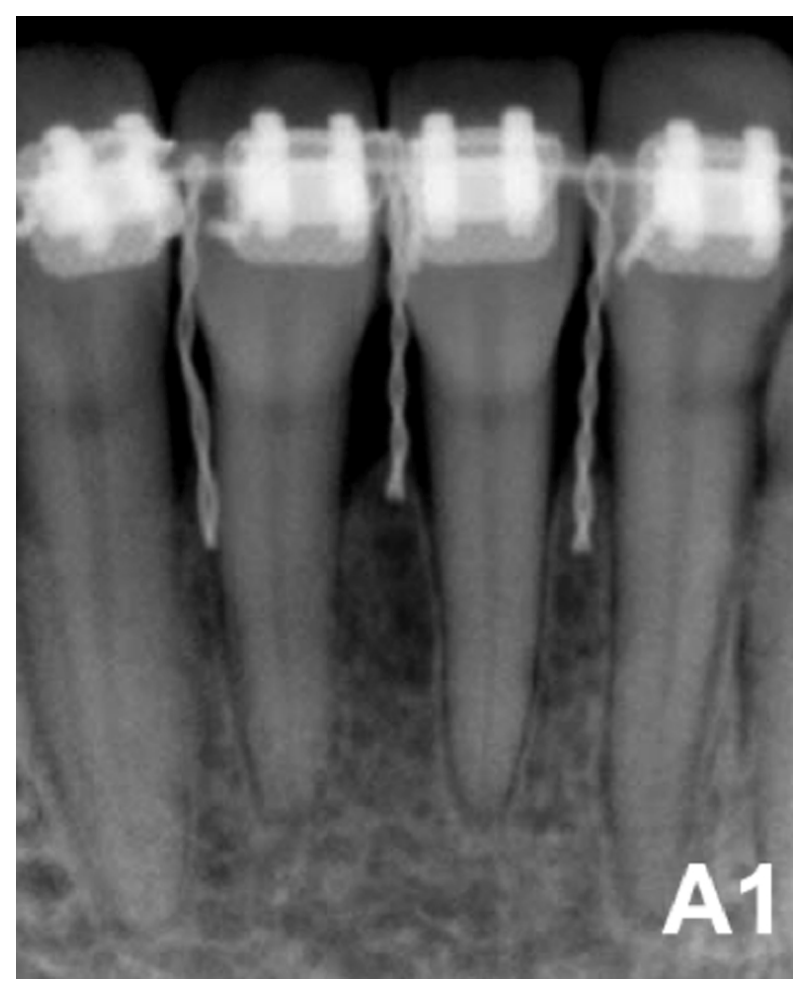

Fig. 5. Digital X-ray showing metal guides between each tooth.

\section{DISCUSSION}

The combination of orthodontics and corticotomies described up to 2009 , show a positive impact in terms of reducing overall orthodontic treatment times (Wilcko et al., 2009). However, these techniques have not been widely embraced by the dental community since they require extensive full thickness flap elevation and in cases of osteotomy, an invasive procedure associated with postoperative discomfort and a high risk of complications leading to a low acceptance by the patient (Kim et al.). On the other hand, there is no consensus in the literature about different techniques used for surgery and orthodontics (Koudstaal et al.).

The techniques described by Vercelloti \& Podesta, and Chung et al. rely on computerized tomography (CT) as reference point for the surgical procedure, whereas the corticotomy of Dibart et al., (2010) use a periodontal probe to stretching the incision to see the osseous and dental anatomy.

Neither technique is sufficiently accurate because both lack radiographic reference points as guide for the surgical procedure. 


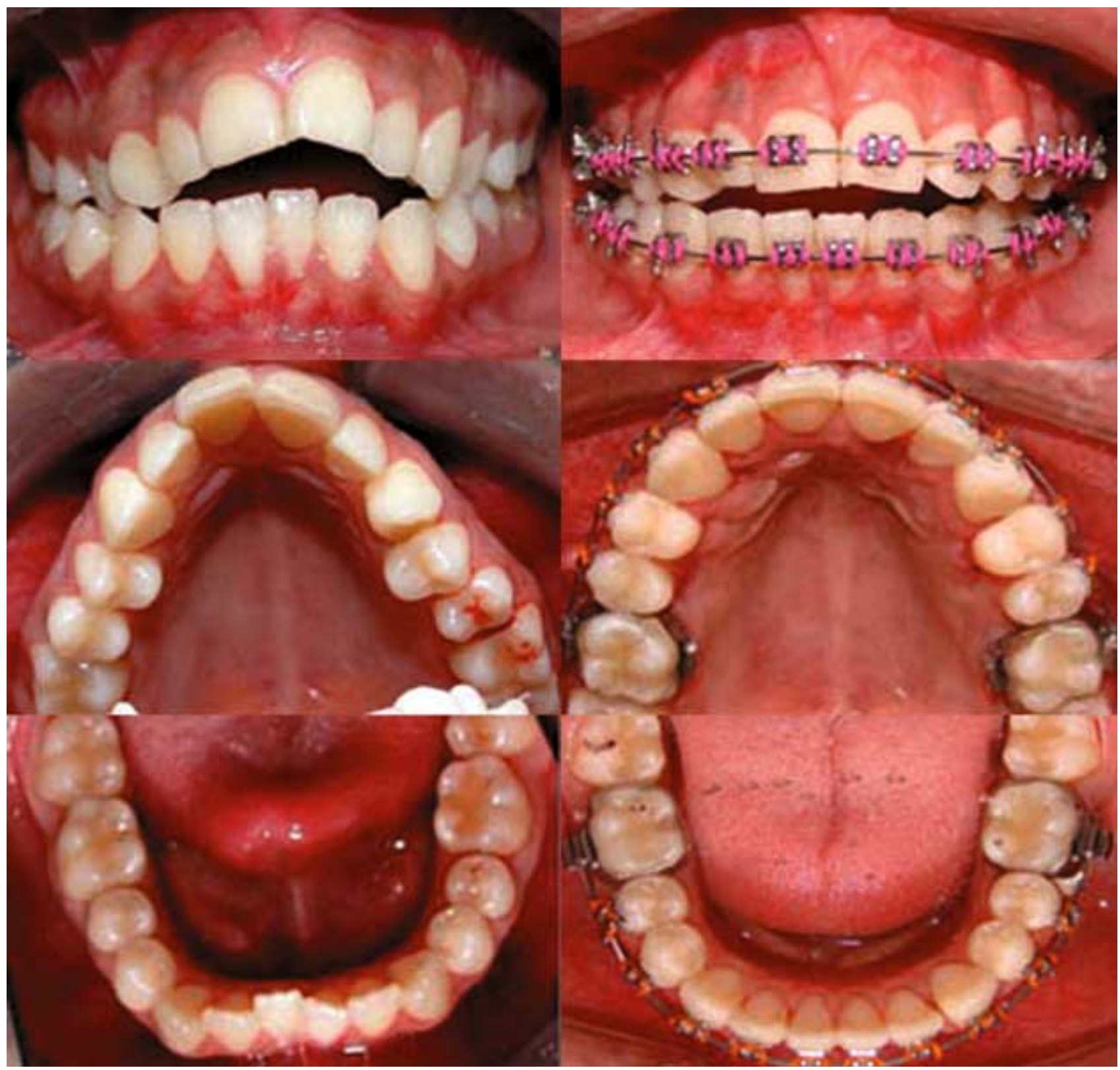

Fig. 6. To the left: Pretreatment frontal and occlusal view. To the right: The same views two months after piezoelectric corticotomies.

This report proposes a technique that uses metal markers as radiographic references or guides for accurate corticotomy by means of intraoral periapical radiographies. Moreover, a minimally invasive flapless procedure is described. Due to its atraumatic nature, this procedure promotes healing without edema or patient discomfort.

Special care should be taken to carry out the corticotomy towards the orthodontic movement. If an arch expansion or dental protrusion is required, the incisions must be made using a buccal approach. In case of arch closure, a lingual approach is indicated (Vercellotti \& Podesta; Wilcko et al., 2009).

This physical injury evokes a regional acceleratory phenomenon (RAP) (Bogoch et al.; Cho et al.; Dibart et al., 2010; Frost) that involves a temporary osteopenia responsible for the rapid tooth movement (Dibart et al., 2010). 
The increased cellular activity is transitory and thus, requires orthodontic setting every two weeks. The reason for the 2 weeks is to maximize the exploitation of the three- to four-month limited window of opportunity following RAP, where the bone is more pliable allowing to move teeth rapidly through the demineralized bone matrix (Lee et al.). This window of opportunity lasts for a few months before the alveolar bone remineralization occurs, hence the need to see the patients every two weeks to take advantage of this phenomenon.

Dibart et al. (2009) proposes a technique that changes the flap for the tunnelization. However, this procedure is complex, and it is also quite difficult to be sure that the graft is placed under the periostium. Furthermore, it is not clear how the corticotomy can be performed between each tooth by means of tunnelization. This approach does not allow a corticotomy in between each tooth, a condition that produces accelerated movement.

Wilko et al. (2009), Vercelloti \& Podesta and Dibart et al., (2010) have proposed the need for grafting to compensate for bone resorption and improve the volume of the buccal osseous wall. Nevertheless, in conventional orthodontic procedures, this kind of bone graft is not necessary. In addition, the need for a flap to elevate the periostium exposes the bone and enhances the risk of resorption of the thin labial/buccal bone plate at the level of the root (Barros et al., 2009).

The proposed technique avoids the elevation of the flap, retaining the characteristics of conventional orthodontics, which normally do not require bone grafts.

In cases requiring bone graft or the correction/ grafting of a thin gingival biotype, a more precise, less risky, second-stage surgery should be utilized.

The orthodontic results obtained with the minimally invasive technique proposed herein are similar to those observed in the literature by Wilko et al., (2009) and Vercelloti \& Podesta, and treatment times are reduced by $30 \%$ to $70 \%$ compared with conventional orthodontic treatments.

Minimally invasive rapid orthodontics (MIRO) is a procedure that shows evident reduction of orthodontic treatment time, avoiding the adverse effects of accelerated orthodontics reported in the literature.

Clinical trials are necessary to extend knowledge and to recommend it as a standard procedure.

JOFRE, J.; MONTENEGRO, J. \& ARROYO, R. Ortodoncia rápida con corticotomías piezoeléctricas sin colgajo: Primeras experiencias clínicas. Int. J. Odontostomat., 7(1):79-85, 2013.

RESUMEN: Uno de los mayores desafíos que enfrenta un paciente de ortodoncia es el tiempo que lleva usar brackets. A través de los años, varias técnicas quirúrgicas se han desarrollado para hacer frente a este problema y reducir el tiempo total de tratamiento. Estas combinan los mecanismos de cicatrización ósea, con cargas de ortodoncia para acelerar el movimiento de los dientes. Aunque eficaz, estas técnicas son bastante invasivas, que requieren la elevación de colgajos bucales y linguales de espesor total con decorticaciones extensas del hueso alveolar bucal y lingual. Por otra parte, con estas técnicas se corre el riesgo de desvitalización dentaria, necrosis avascular del bloque óseo, reabsorción alveolar, y los riesgos de complicaciones, con baja aceptación por parte del paciente. Este trabajo reporta tres casos tratados con un nuevo enfoque sin colgajo para ortodoncia rápida mínimamente invasiva (MIRO - minimally invasive rapid orthodontic). Este procedimiento incluye microincisiones guiadas por radiografías y corticotomías piezoeléctricas localizadas. Las implicaciones clínicas de esta técnica se analizan en este documento. MIRO reduce el tiempo de tratamiento de ortodoncia, evitando los efectos adversos reportados por la ortodoncia acelerada.

PALABRAS CLAVE: movimiento dentario, procedimientos quirúrgicos, mínimamente invasivo, piezoquirúrgicas.

\section{REFERENCES}

Aboul-Ela, S. M.; El-Beialy, A. R.; El-Sayed, K. M.; Selim, E. M.; El-Mangoury, N. H. \& Mostafa, Y. A. Miniscrew implant-supported maxillary canine retraction with and without corticotomy-facilitated orthodontics. Am. J. Orthod. Dentofacial Orthop., 139:252-9, 2011.
Barros, R. R.; M. Novaes Jr, A. B. \& Papalexiou, V. Buccal bone remodeling after immediate implantation with a flap or flapless approach: a pilot study in dogs. The International Journal of Dental Implants and Biomaterials Titanium, 1:45-51, 2009. 
Bogoch, E.; Gschwend, N.; Rahn, B.; Moran, E. \& Perren, S. Healing of cancellous bone osteotomy in rabbits--Part I: Regulation of bone volume and the regional acceleratory phenomenon in normal bone. J. Orthop. Res., 11:285-91, 1993.

Cho, K. W.; Cho, S. W.; Oh, C. O.; Ryu, Y. K.; Ohshima, H. \& Jung, H. S. The effect of cortical activation on orthodontic tooth movement. Oral Dis., 13:314-9, 2007.

Chung, K. R.; Kim, S. H. \& Lee, B. S. Speedy surgicalorthodontic treatment with temporary anchorage devices as an alternative to orthognathic surgery. Am. J. Orthod. Dentofacial Orthop., 135:787-98, 2009.

Dibart, S.; Sebaoun, J. D. \& Surmenian, J. Piezocision: a minimally invasive, periodontally accelerated orthodontic tooth movement procedure. Compend. Contin. Educ. Dent., 30:342-4, 346, 348-50, 2009.

Dibart, S.; Surmenian, J.; Sebaoun, J. D. \& Montesani, L. Rapid treatment of Class II malocclusion with piezocision: two case reports. Int. J. Periodontics Restorative Dent., 30:487-93, 2010.

Ferguson, D. J.; Wilcko, W. M. \& Wilcko, T. M. Accelerating orthodontics by altering alveolar bone density. Good Practice, 2:2-4, 2001.

Frost, H. M. The regional acceleratory phenomenon: a review. Henry Ford Hosp. Med. J., 31:3-9, 1983.

lino, S.; Sakoda, S.; Ito, G.; Nishimori, T.; Ikeda, T. \& Miyawaki, S. Acceleration of orthodontic tooth movement by alveolar corticotomy in the dog. Am. J. Orthod. Dentofacial Orthop., 131:448 e1-8, 2007.

Kim, S. J.; Park, Y. G. \& Kang, S. G. Effects of Corticision on paradental remodeling in orthodontic tooth movement. Angle Orthod., 79:284-91, 2009.

Kole, $\mathrm{H}$. Surgical operations on the alveolar ridge to correct occlusal abnormalities. Oral Surg. Oral Med. Oral Pathol., 12:515-29, 1959.

Koudstaal, M. J.; Poort, L. J.; van der Wal, K. G.; Wolvius, E. B.; Prahl-Andersen, B. \& Schulten, A. J. Surgically assisted rapid maxillary expansion (SARME): a review of the literature. Int. J. Oral Maxillofac. Surg., 34:709-14, 2005.

Lee, W.; Karapetyan, G.; Moats, R.; Yamashita, D. D.; Moon, H. B.; Ferguson, D. J. \& Yen, S. Corticotomy-/osteotomyassisted tooth movement microCTs differ. J. Dent. Res., 87:861-7, 2008.

Liou, E. J. \& Huang, C. S. Rapid canine retraction through distraction of the periodontal ligament. Am. J. Orthod. Dentofacial Orthop., 114:372-82, 1998.
Mostafa, Y. A.; Mohamed Salah Fayed, M.; Mehanni, S.; ElBokle, N. N. \& Heider, A. M. Comparison of corticotomyfacilitated vs standard tooth-movement techniques in dogs with miniscrews as anchor units. Am. J. Orthod. Dentofacial Orthop., 136:570-7, 2009.

Young-Guk, P.; Seung-Goo, K. \& Su-Jung, K. Accelerated Tooth Movement by Corticision as an Osseous Orthodontic Paradigm. J. Kinki-Tokai Orthod. Soc., 41:62, 2006.

Penarrocha-Diago, M.; Rambla-Ferrer, J.; Perez, V. \& PerezGarrigues, H. Benign paroxysmal vertigo secondary to placement of maxillary implants using the alveolar expansion technique with osteotomes: a study of 4 cases. Int. J. Oral Maxillofac. Implants, 23:129-32, 2008.

Ren, A.; Lv, T.; Kang, N.; Zhao, B.; Chen, Y. \& Bai, D. Rapid orthodontic tooth movement aided by alveolar surgery in beagles. Am. J. Orthod. Dentofacial Orthop., 131:160 e1-10, 2007.

Sanjideh, P. A.; Rossouw, P. E.; Campbell, P. M.; Opperman, L. A. \& Buschang, P. H. Tooth movements in foxhounds after one or two alveolar corticotomies. Eur. J. Orthod., 32:106-13, 2010.

Vercellotti, T. \& Podesta, A. Orthodontic microsurgery: a new surgically guided technique for dental movement. Int. J. Periodontics Restorative Dent., 27:325-31, 2007.

Wilcko, M. T.; Wilcko, W. M.; Pulver, J. J.; Bissada, N. F. \& Bouquot, J. E. Accelerated osteogenic orthodontics technique: a 1-stage surgically facilitated rapid orthodontic technique with alveolar augmentation. J. Oral Maxillofac. Surg., 67:2149-59, 2009.

Wilcko, W. M.; Wilcko, T.; Bouquot, J. E. \& Ferguson, D. J. Rapid orthodontics with alveolar reshaping: two case reports of decrowding. Int. J. Periodontics Restorative Dent., 21:9-19, 2001.

Correspondence to:

Jorge Jofre DDS, PhD

Director

Center for Advanced Prosthodontic and Implantology

CRAI

Universidad de Concepción

Victoria 232, Concepción

CHILE

Email jjofre@udec.cl

Received: 31-5-2012

Accepted: 10-8-2012 